\title{
Hijab Martyrdom, Headscarf Debates: Rethinking Violence, Secularism, and Islam in Germany
}

\author{
Beverly M. Weber
}

$T$

he ongoing and contentious debates on the presence of the hijab in public space in Europe present a particular challenge to critical theory and its impulse to critique. Discourses surrounding forms of Islamic head covering exist at a complex intersection of notions of democracy, freedom, secularism-and of critique itself, which historically has been attached to a particular understanding of secularism. In the case of Germany, negotiations concerning the figure of the Muslim woman in relationship to secularism, democracy, violence, and public space play an important, yet ambivalent, role in a national narrative, one which imagines a Germany that has successfully emerged from the shadow of the Shoah to embrace a democratic identity. The ambiguities inherent in such a narrative are revealed in the contrasting response to two women who both emerged in the public eye based on their wearing of the headscarf yet are rarely discussed in relationship to each other. In this article I consider the popular representations of Germany's so-called headscarf debate, in which Fereshta Ludin sought placement as a public school teacher, and of the murder of Marwa el-Sherbini, who was dubbed the "hijab martyr" after her death in a German courtroom at the hands of a xenophobic man with ethnic German heritage. The juxtaposition of these two figures reveals the difficulty of and need for a critique of headscarf discourses. In the case of Ludin, the portrayal of the German state as the patronizing protector of the Muslim woman serves to legitimate the exclusion of those of immigrant heritage from participation in the public sphere. Similarly, the emphasis on the failure of the German state to protect el-Sherbini from an armed man in the courtroom functions to distract from an examination of racism in contemporary Germany. A critique of headscarf discourses thus reveals the need to theorize anew the relationship among modernity, religious difference, secularism, and violence. Such a theorization must address the role of racism in German democracy, construct new relationships between religious/communal attachment and notions of the public/private, and provide new understandings of secularism and its relationship to a nonviolent future.

\section{Secularism, Post-secularism, Europe}

The difficulty of a critique of the discourse of the veil lies at least partly in the history of the European tradition of critique itself. As Wendy Brown has recently reminded us, the notion of critique that eventually gave birth to the body of theory we today call critical theory is rooted in the Enlightenment assumption that religious perspectives must be shed in order to 
enable rational critique, understood as an apprehension of the conditions of possibility for any particular phenomenon. ${ }^{1}$ The legacy of this thought leads to Karl Marx's distinction between critique and criticism, in which criticism merely evaluates or judges religion, while critique is able to apprehend the social and economic conditions that require religious illusion. ${ }^{2}$ How, then, to formulate a critique of the discourse of religion that draws on the insights of critical theory? This can function only to the extent to which critical theory can be turned against itself: it requires critique of the foundations of critique, in particular, the presumed necessary relationship between a form of secularism that relegates religion to the private and an effective, inclusive democracy. While the structure of such a move is certainly not contrary to the spirit of critical theory, it has proven difficult to enact in relationship to religion.

Consider, for example, the notion of the public sphere-more specifically, the role that the wearing of Islamic head coverings has played in excluding Muslim women from active participation in the European public sphere. Jürgen Habermas's early elaborations of the public sphere see it as an emancipatory space that emerges from rational deliberation on common issues, ideally resulting in polices that will serve the common good. An effective public sphere must remain inclusive and guarantee access to all citizens but, to do so, transcends and brackets out difference in order to seek the common good. ${ }^{3}$ Even today, many cultural critics of forms of racism in Germany replicate this assumption that difference can be "productive" only in the private sphere. ${ }^{4}$ A number of challenges to Habermas's early theories of the public sphere quickly emerged. For example, a large body of feminist research argues that in bracketing out difference (or relocating difference to the private sphere), the public sphere in effect works against the common good by excluding women. ${ }^{5}$ The early modern public sphere actually functioned to enable the concerns of middle- and upper-class European men to be represented as universal; the public sphere continues to exclude those produced as others within any given society. Chantal Mouffe has further argued that the notion of the public sphere may go so far as to eliminate not only difference but all public dissent. ${ }^{6}$ The most radical critiques seek not to amend a normative public sphere to be more inclusive but to suggest that the public sphere actually produces dominance and power. "Difference" does not exist outside the public sphere but is produced by it; ${ }^{7}$ the expulsion of that viewed as other by necessity privileges the dominant groups, who serve as the norm against which difference is defined. Indeed, the public sphere, by seeking to exclude certain forms of difference, produces marked bodies in opposition to an abstracted, disembodied subject of the public sphere. ${ }^{8}$

Mouffe has further argued for considering difference as fundamental to the proper functioning of the public sphere. She suggests that the desire for reconciliation, or for elimination of difference, that haunts many liberal conceptions of the public sphere prevents effective public debate. ${ }^{9}$ This dilemma derives in part from the tendency to conflate the separations between church and state, religion and politics, and public and private, and in part from the conflation of politics with state politics. If what is truly at stake is the separation between religion and state power, there is no reason to prohibit religious groups or individuals from interven-
1. See Wendy Brown, introduction to Is Critique Secular? Blasphemy, Injury, and Free Speech, by Talal Asad, Wendy Brown, Judith Butler, and Saba Mahmood, Townsend Papers in the Humanities 2 (Berkeley: University of California Press, 2009), 11.

2. See ibid., 12.

3. See Jürgen Habermas, "The Public Sphere: An Encyclopedia Article (1964)," New German Critique 3 (1974): 49.

4. See, e.g., Mark Terkessidis, "Wir selbst sind die Anderen: Globalisierung, multikulturelle Gesellschaft und Neorassismus" ("We Are the Others: Globalization, Multicultural Society and Neoracism"), in Zuwanderung im Zeichen der Globalisierung: Migra- tions-, Integrations- und Minderheitenpolitik (Immigration under the Sign of Globalization: Migration, Integration, and Minority Politics), ed. Christoph Butterwege and Gudrun Hentges (Opladen, Germany: Leske and Budrich, 2000), 204.

5. See Iris Marion Young, "Impartiality and the Civic Public: Some Implications of Feminist Critiques of Moral and Political Theory," Praxis International 4 (1985): 381-401; and Nancy Fraser, "Rethinking the Public Sphere: A Contribution to the Critique of Actually Existing Democracy," Social Text, no. 25 (1990): 56-8o.

6. See Chantal Mouffe, The Democratic Paradox (New York: Verso, 2000), 30.
7. See Alev Çınar, "Subversion and Subjugation in the Public Sphere: Secularism and the Islamic Headscarf," Signs: Journal of Women in Culture and Society 33 (2008): 892-93.

8. See ibid. See also Lauren Berlant, The Queen of America Goes to Washington City: Essays on Sex and Citizenship (Durham, NC: Duke University Press, 1997).

9. See Chantal Mouffe, "Religion, Liberal Democracy, and Citizenship," in Political Theologies: Public Religions in a Post-secular World, ed. Hent de Vries and Lawrence E. Sullivan (New York: Fordham University Press, 2006), 320. 


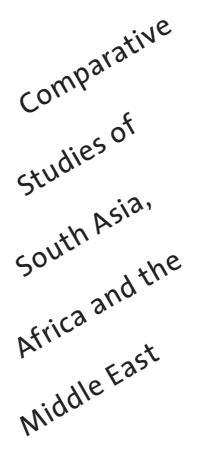

tion in the larger political arena. ${ }^{10}$ The problem rather emerges when certain religious communities, or members or symbols of those communities, are allowed to appear in public space, while others are not. Recent laws in several German provinces that ban Islamic symbols from classrooms, particularly the headscarf, while permitting Judeo-Christian symbols provide an excellent example. While ostensibly protecting the secular space of the school, Christian and Jewish groups and symbols have been privileged in the name of secularism.

Habermas himself has reconsidered how to think difference in relationship to secularism and the public sphere, but with a particular focus on religious language. He recently engaged in a series of conversations with the intention of articulating the possibility for rethinking the notion of politics in what he (with ambivalence) has called a "post-secular" Europe. Habermas's remarks have been particularly surprising in their willingness to articulate a place for religious language in public political discussions. Here I would like to highlight a few points from his essay "Notes on a Post-secular Society."

In his essay Habermas repeats the traditional narrative of secularism in Europe as a path to peace after the confessional wars. Historically, secularism was thought to provide a strategy for ending the violence of religious conflict by managing the relationship between religion and the public (particularly the state) by relegating religion specifically to the private. While Habermas wishes to consider whether Europe has moved into a postsecular age, the use of the term post is deceiving, for in his understanding, "post-secularism" is an age in which one must "adjust" to the "continuing existence" of religious communities. ${ }^{11}$ As a consequence, Habermas now argues that religious language, at least, must be permitted in the public sphere. Public disputes over religion can provide a space in which subjects of democracy may emergein finding common political ground, the indi- vidual cultural identities can be maintained even as people see themselves as participants in a common political community. ${ }^{12}$

This intervention complicates the understandings of the public sphere in order to redress the potential for exclusion on grounds of religious affiliation. If we define language broadly, we could conclude that Habermas's argument suggests that the headscarf, as a symbol of Islam, should be allowed in public space. However, Habermas falls short of providing a conceptual framework for addressing the fixation on forms of Islamic head covering, one that produces the Muslim woman's body as hypervisible in Western societies while excluding Muslim women from public sphere participation. This fixation partially rests on the assumption of the inherent violence of Islam. In the debates about the role of Islam in Germany, the incommensurability of Islam with the ideals of European modernity are often fundamentally related to controversies about human rights, particularly rights to bodily integrity and gender equality. Yet Habermas, who has championed Germany as part of the "avantgardist core" of Europe to be at the forefront of a Europe committed to human rights, seems unable to address the controversies about women's rights and violence against women that have been such an important part of the debates on integration, Islam, and Europe. ${ }^{13}$ His focus on defining the extent of secularism by the numbers of people participating in religious communities also is unable to engage with the aspects of the state that institutionalize forms of Christianity in many Western European countries-via management of religious education, for example. His focus on identity (in terms of cultural difference) instead of embodied practices (like the wearing of the headscarf) further limits his discussion of secularism.

These omissions in Habermas's considerations of the possibilities for a postsecular $\mathrm{Eu}$ rope have been at least partially addressed in another context. Anthropologist Talal Asad, who

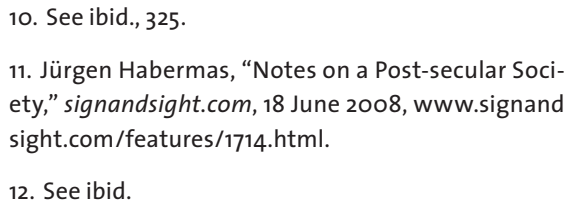

13. Jürgen Habermas and Jacques Derrida, "February 15, or, What Binds Europeans Together: Plea for a Common Foreign Policy, Beginning in Core Europe," in Old Europe, New Europe, Core Europe: Transatlantic Relations after the Iraq War, ed. Daniel Levy, Max Pensky, and John Torpey (New York: Verso, 2005), 3-13. 
seeks to write an "anthropology of the secular" in Europe, has elaborated on the epistemological assumptions of the secular, with a particular interest in pain and torture as mechanisms by which the secular human becomes a human subject during the Enlightenment. ${ }^{14}$ While he addresses a radically different context than I do, he makes some intriguing assertions about violence and secularism that are useful in considering the role that veils and headscarves play in discussions of secular and postsecular Europe.

While dominant narratives of the Enlightenment see secularism as an important means to peace via tolerance, Asad suggests that "a secular state does not guarantee toleration; it puts into play different structures of ambition and fear. The law never seeks to eliminate violence since its object is always to regulate violence" (8). Thus violence is regulated by the state in part by the regulation of difference through structures of "toleration." Membership in or exclusion from the state is inextricably linked to the regulation of difference: "Secularism is not simply an intellectual answer to a question about enduring social peace and toleration. It is an enactment by which a political medium (representation of citizenship) redefines and transcends particular and differentiating practices of the self that are articulated through class, gender, and religion" (5). Influenced by postcolonial theory, Asad writes a narrative of European history in which the violence of Europe's religious wars is not eliminated by secularism but rather transformed into the violence of national and colonial wars. Thus secularism has been not a path to peace but rather a means of displacing violence. Asad sees a continuing secular violence that has colonialism as its heritage, a "violence lying at the heart of a political doctrine that has disavowed violence on principle." We might call this continued violence a symbolic and epistemic violence that enables forms of racialized violence. This requires the cultivation of an other, a "dark jungle" against which the Enlightenment can be defined (59).

Bringing these two very different scholars into dialogue suggests that a European secular- ism as the management of public and private

spheres in order to end religious violence is actually founded on the epistemic violence of constructing an other, one that legitimates the actions of the nation-state through the regulation-but not prohibition-of violence. The complex interactions of these aspects of secularism today produce a very limited space in which Muslim women can participate in the public sphere. The construction of the other occurs in part through the attention to violence against Muslim women and the endless discussions about headscarves-both constantly represented as "new, invisible" crises that are inextricably linked to each other. Strategies presented against gender violence, however, can also serve to prevent Muslim women from participating in the political sphere. A very obvious example of this is the federal working group on Islam and Germany referred to as the IslamKonferenz, in which many of the women chosen to represent the Muslim community are women who have rejected Islam as inherently antithetical to European modernity. This decision rests on the assumption that the headscarf signals a form of gender violence. In a complex series of slippages, a threatened political violence is then seen to be indicated by domestic violence, visually signaled by the headscarf. The figure of the covered woman participating in German citizenship defines and troubles a boundary between public and private, religious and secular; her exclusion from the Islam-Konferenz manages that boundary confusion. In this way a certain form of secularism, while advocated as a path to the end of gender violence, ultimately excludes Muslim women from participation in the public sphere.

\section{Contextualizing the Headscarf in the German Context}

A visual imagination of the veiled or covered Muslim woman has long played a role in German thought, art, and literature. I discuss a much longer historical trajectory elsewhere; here I confine my discussion to the role played by the figure of the Muslim woman in the con- 


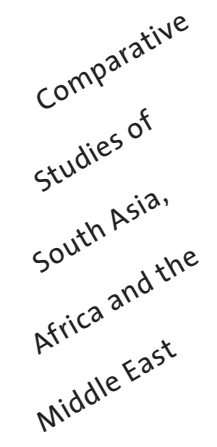

text of Germany's postwar labor migration. ${ }^{15}$ Beginning in the $195^{\circ}$, Germany signed guestworker contracts with a number of countries; Turkey became the largest "sending" country after the building of the Berlin Wall cut off immigration from East Germany. ${ }^{16}$ Today, some 4 million residents of Germany are Muslim. Owing to Germany's traditionally restrictive citizenship laws, only 45 percent of Muslim residents in Germany have German citizenship. ${ }^{17}$ While Muslims from southeast Europe now outnumber Turkish Muslims in Germany, discussions in Germany are heavily influenced by the history of Turkish migration, as well as the traditions of Turkish secularism. ${ }^{18}$

The figure of the covered immigrant woman capturing the imagination of the German public and dominating discussions of immigration in Germany over the previous decades has evolved significantly. The cleaning woman, the Kopftuchfrau (headscarf woman), of the 1970 and 1980 s was a figure both less threatening and less present in the popular imagination. This representation focused on national, class, and educational difference to locate immigrant culture in a rural, traditional, distant past. This figure occasionally alternated with the exoticized body of a belly dancer, or a woman in a niqab, but dominant representations located difference in class and education. ${ }^{19}$

Gradually, however, and in particular after unification, representations of immigrant women in Germany shifted to emphasize cultural difference - in particular, cultural difference located in Islam. The 1997 cover from the respected weekly news magazine Der Spiegel marks this transition - the difference located in a nation remains at the forefront, but in the background sit the quiet Kopftuchmädchen (headscarf girls), who are emerging as a dominant image of Islam. They are accompanied by their dangerous, criminal brothers, whose violence is represented in their stance, facial expression, and the weapons they carry.

This shift to an emphasis on cultural difference, expressed as religious difference, came to a head in 1997 when Fereshta Ludin, a German citizen in the province of Baden-Württemberg, sought placement as a public school teacher while wearing a hijab. The right-wing party Republikaner challenged her placement in a parliamentary debate, initiating a widely covered headscarf debate, referred to in German as the Kopftuchstreit. During this debate the hijab was alternately seen as a threat to German secularism, Christian culture, feminist progress, Enlightenment, and European values.

The forbidden schoolteacher revealed fears as the immigrant woman became upwardly mobile and began to emerge as a German and European subject-one who has access to economic, political, and cultural citizenship, and one who, as teacher, would play a key role in the reproduction of notions of citizenship.

Representations of the murder of Marwa el-Sherbini in this trajectory are revealing in terms of the possibilities for cultural, political, and economic citizenship afforded to Muslim women. In July 2009, el-Sherbini, an Egyptian citizen, was killed in a courtroom after bring-
15. See Beverly M. Weber, "Cloth on Her Head, Constitution in Hand: Germany's Headscarf Debates and the Cultural Politics of Difference," German Politics and Society 22, no. 3 (2004): 33-63. An excellent examination of the construction of the Oriental woman in the context of colonial fantasies is Meyda Yeğenoğlu, Colonial Fantasies: Towards a Feminist Reading of Orientalism (Cambridge: Cambridge University Press, 1998). Several scholars have examined aspects of the role of the image of the veiled woman in constructing a racialized or "ethnic" other in contemporary German culture, including Manuela Westphal, "Arbeitsmigrantinnen im Spiegel westdeutscher Frauenbilder" ("Worker Migrants as Reflected in West German Images of Women"), Beiträge zur feministischen Theorie und Praxis 19, no. 42 (1996): 17-28; Mark Terkessidis, "Globale Kultur in Deutschland oder: Wie unterdrückte Frauen und Kriminelle die Hybridität retten" ("Global Culture in Germany, or How Oppressed Women and Criminals Are Rescuing Hybridity"), in Kultur-Medien-Macht:
Cultural Studies und Medienanalyse (Culture-MediaPower: Cultural Studies and Media Analysis), ed. Andreas Hepp and Rainer Winter (Wiesdaden: VS Verlag für Sozialwissenaften, 1999), 2:237-52; Helma Lutz, “Unsichtbare Schatten? Die 'orientalische' Frau in westlichen Diskursen-Zur Konzeptualisierung einer Opferfigur" ("Invisible Shadows? The 'Oriental' Woman in Western Discourses-Toward a Conceptualization of a Victim Figure"), Peripherie 37 (1989): 51-65; and Christine Huth-Hildebrandt, Das Bild von der Migrantin: Auf den Spuren eines Konstrukts (The Image of the Migrant Woman: Tracking a Construct) (Frankfurt: Brandes and Apsel, 2002). Verschleierte Wirklichkeit also provides a comparative perspective of representation of women in Islam, Judaism, and Christianity as well as the construction of the Muslim woman by the West. See Christina Von Braun and Bettina Mathes, Verschleierte Wirklichkeit: Die Frau, der Islam und der Westen (Veiled Reality: Woman, Islam, and the West) (Berlin: Aufbau-Verlag, 2007).
16. An excellent discussion of early discourses at work in conjunction with worker migration is Rita Chin, The Guest Worker Question in Postwar Germany (Cambridge: Cambridge University Press, 2009).

17. See Sonja Haug, Stephanie Müssig, and Anja Stichs, Muslimisches Leben in Deutschland im Auftrag der Deutschen Islam Konferenz: Forschungsbericht 6 (Muslim Life in Germany, Commissioned by the German Islam-Conference: Research Report 6) (Nuremberg: Bundesamt für Migration und Flüchtlinge, 2009).

18. See ibid.

19. See Irmgard Pinn and Marlies Wehner, EuroPhantasien: Die islamische Frau aus westlicher Sicht (EuroFantasies: The Muslim Woman from a Western Perspective) (Duisburg, Germany: Duisburger Institut für Sprach- und Sozialforschung, 1995), 39; HuthHildebrandt, Das Bild, 46; and Westphal, "Arbeitsmigrantinnen im Spiegel westdeutscher Frauenbilder." 
ing charges against Alex Wiens. Wiens, a sympathizer of the right-wing National Democratic Party (NPD), had called her an Islamist and terrorist at a playground when she asked him to allow her son to use a swing. At the time of her murder, el-Sherbini had just completed her testimony against Wiens, who had appealed his fine for insulting speech. While the murder quickly gained attention in Egypt (el-Sherbini's home country) and Iran, seen as an example of growing European Islamophobia, the German press did not react to the case for nearly a week. By the time German officials and the media did respond, el-Sherbini was being referred to as a "hijab martyr" in the Islamic world, and her death acknowledged as the first Islamophobic murder in Germany. Yet discussions of her case relocated violence outside of Europe, to the anti-European sentiment of the so-called Muslim world. The reduction of her case to an example of martyrdom abroad and to a woman insufficiently protected by the German state in German coverage both exclude her from participation in democratic public spheres.

Read together, the discourses surrounding the cases of Ludin and el-Sherbini reveal some interesting points about the contemporary German debates on integration. Neither one involves a Turkish German, yet both are used to examine the experience of the Turkish immigrant population as Germans. In one, a German citizen claims her rights to religious freedom under the German constitution in order to be allowed to teach wearing the headscarf. El-Sherbini, an Egyptian citizen, claimed her rights under German law and the constitution to testify against Wiens for Beleidigung aus Fremdenhass (xenophobically motivated slander). While the headscarf played a marginal role in el-Sherbini's case, she became known as the headscarf martyr.

Reading these two cases together demonstrates the difficulty of engaging intersec- tional differences in the German public sphere.

As Susan B. Rottmann and Myra Marx Ferree point out, public discussions have been largely unable to include a focus on race. Not only is this focus absent in terms of its intersection with gender and other forms of difference, but even in terms of the importance of antiracism in European values, or in terms of European Union (EU) policies. Court cases about whether public school teachers can wear headscarves to work dominate public discourse, while debates about German compliance with the EU antidiscrimination laws are largely avoided. ${ }^{20}$ While Ludin's headscarf was viewed as indicative of the wideranging violent impacts of a growing Islamism, el-Sherbini's death, once it finally appeared in the press, it was viewed as an isolated instance. Despite a recent spike in incidents in racist violence, journalists, politicians, and even representatives of Muslim organizations took pains to emphasize that the murder of el-Sherbini was not evidence of extensive institutionalized racism or Islamophobia.

\section{Fereshta Ludin and the Headscarf Debates}

Germany's incarnation of headscarf debates chronologically roughly parallels the emergence of France's second "affair of the veil." ${ }^{21}$ In 1997 Ludin had completed preparation for a career as a teacher and was ready to be placed in a studentteaching position. The Republikaner, which at that time had seats in the Baden-Württemberg parliament, initiated a parliamentary debate in which the party argued that the BadenWürttemberg constitution must be honored, in which it states that "youth are to be raised in the fear of God [...] Children will be raised on the basis of Christian and Western educational and cultural values." 22

Because of the state's monopoly on teacher training and education, Ludin was placed as a student teacher in a public school. ${ }^{23}$ Ludin suc-
20. See Susan B. Rottmann and Myra Marx Ferree, "Citizenship and Intersectionality: German Feminist Debates about Headscarf and Antidiscrimination Laws," Social Politics: International Studies in Gender, State and Society 15 (2008): 481-513.

21. For a discussion of the French headscarf debates in the context of racist and colonial discourses, see Joan Wallach Scott, The Politics of the Veil (Princeton, NJ: Princeton University Press, 2007). On the extensive discussion of the French headscarf debates, see
Jane Freedman, "Secularism as a Barrier to Integration? The French Dilemma," International Migration 43, no. 3 (2004): 5-28; Christian Joppke, "State Neutrality and Islamic Headscarf Laws in France and Germany," Theory and Society 36 (2007): 313-42; and Bronwyn Winter, "Secularism aboard the Titanic: Feminists and the Debate over the Hijab in France," Feminist Studies 32 (2006): 279-98.

22. Landtag von Baden-Württemberg, Plenarprotokoll 12/23, 20.03.97, 20 March 1997, 1632.
23. See Annette Schavan, Antrag der Abg. Helmut Rau u. a. CDU und Stellungnahme des Ministeriums für Kultus, Jugend und Sport Islamische Lehrkraft im Vorbereitungsdienst-Islamischer Religionsunterricht in deutscher Sprache (Application of Representative Helmut Rau et al., CDU and Position Statement of the Ministry of Culture, Youth, and Sport. Islamic Teacher in Training-Islamic Religious Instruction in the German Language), 29 April 1997; and Thorsten Schmitz, Kein Stoff für die Schule: Der Fall Ludin; Wer steckt unter dem Tuch? (No Cloth for School: The Case of 


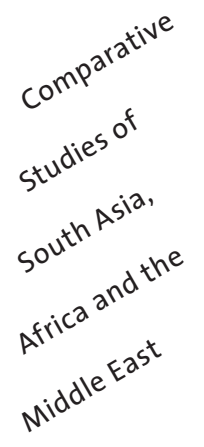

cessfully completed her two years as a student teacher and received good grades and positive feedback. No parental complaints were lodged against her. ${ }^{24}$ However, after completing her student teaching, she was prevented from placement as a public school teacher. Then minister of culture Annette Schavan reasoned that as the wearing of the headscarf is controversial and not clearly required by the Koran, its wearing must be an inherently political symbol, yet one that infringes on a student's freedom from religious participation (negative religious freedom) ${ }^{25}$ One must note here that the wearing of a Christian clerical collar or nun's habit by public school teachers had not been questioned in these discussions.

Ludin then sued for the right to a teaching position. She argued that her headscarf was a personal decision, an article of clothing worn for religious reasons but without a desire to missionize for Islam. The lower courts found against Ludin, citing state neutrality, Ludin's inability to fulfill her duties as a civil servant, and the "visibility" and "demonstrative character" of the headscarf, regardless of Ludin's intentions. ${ }^{26}$ The conflict between Ludin's freedom of religion and Baden-Württemberg's rootedness in Christian values, said the court, must necessarily be resolved to Ludin's disadvantage in order to affirm Christianity's place in the provincial constitution, which is one of relationship "only to cultural and educational influence, not to specific religious realities." ${ }^{27}$ In September 2003 the Federal Constitutional Court decided for Ludin (five to three), but on the basis of a lack of existing laws in the Bundesländer (individual provinces) regulating the relationship between church and state in the classroom. ${ }^{28}$ In other words, this decision essentially emphasized that questions regarding education are the purview of provincial, not federal, law. The decision implies that a nondiscriminatory law that treats all religions equally and bans the headscarf could be constitutional: any such law would have to adhere to "strict equality in the handling of different religious beliefs, both in the justification as well as in the enforcement of such employment duties." 29

In the wake of this decision, eight of Germany's sixteen provinces passed headscarf bans. ${ }^{30}$ Note, however, that many headscarf bans have explicitly banned Islamic symbols and permitted Christian symbols, while others are implicitly interpreted to permit Christian and Judaic symbols. The Baden-Württemberg law, for example, reads:

Teachers in public schools ... may not externally represent political, religious, worldview, or other similar positions that would potentially endanger the neutrality of the province vis-a-vis students and parents [...] In particular, external behavior that would evoke the impression by students or parents that the teacher is against human dignity, the equal rights of people according to Article 3 of the Basic Law, the basic freedoms, or the liberal democratic order, is not permissible. [...] Symbols of Christian and Western educational and cultural values or traditions do not infringe on this ban. ${ }^{31}$

Berlin is the only province to pass a law explicitly banning all religious symbols in the classroom. ${ }^{32}$ Ludin challenged the constitutionality of the Baden-Württemberg law but lost before the Federal Administrative Court in June 2004.
Ludin, Who Is Hiding under the Scarf?), Süddeutsche Zeitung, 23 July 1998.

24. See Schmitz, Kein Stofffür die Schule.

25. See Ministerium für Kultus, Jugend und Sport Baden-Württemberg, Pressemitteilung Nr. 119/98, 13 July 1998.

26. See Verwaltungsgericht Stuttgart, "Tragen eines Kopftuchs im Unterricht durch Lehrerin. Urt. v. 24.3.2000-15 K 532/99" "The Wearing of a Headscarf by a Teacher in the Classroom. Decision of 24 March 2000"), Neue Zeitschrift für Verwaltungsrecht 19 (2000): 959-61; Verwaltungsgerichthof Mannheim, "Religiös motiviertes Tragen eines Kopftuchs als Eignungskriterium für Lehramtsbewerberin. Urt. v. 26.6.2001-4 S 1439/oo" ("Religiously Motivated
Wearing of a Headscarf as Criteria for Suitability for Employment for a Teacher Applicant"), Neue Juristische Wochenschrift 54, no. 39 (2001): 2899-2905.

27. Verwaltungsgerichthof Mannheim, "Religiös motiviertes Tragen eines Kopftuchs."

28. Bundesverfassungsgericht (BverfG), 2 BVR 1436/ o2 vom 3.6.2003, 24 September 2003.

29. Ibid.

30. The eight provinces that ban the headscarf are Baden-Württemberg, Bavaria, Berlin, Bremen, Hessen, Lower Saxony, North Rhine-Westphalia, and Saarland. Claudia Breger, "Religious Turns: Immigration, Islam, and Christianity in Twenty-first Century German Cultural Politics," Konturen 1, no. 1 (2008), konturen.uoregon.edu/vol1_Breger.html\#.
31. "Landtag von Baden-Württemberg 13. Wahlperiode. Drucksache 13/3091," 14 April 2004.

32. Thomas Gasparini, “Die Kopftuch-Gesetze der Bundesländer" ("The Headscarf Laws of the Provinces”) Welt Online, 29 August 2004, www.welt.de /print-wams/article11509o/Die_Kopftuch_Gesetze _der_Bundeslaender.html. 
Ludin at this point chose to end her battle in the courts rather than pursue her case back to the Federal Constitutional Court. There was discussion about the European Commission reviewing these laws for adherence to EU antidiscrimination guidelines, but this has not been pursued. This may be because French, Turkish, and Swiss headscarf bans have been declared acceptable by the European Court of Human Rights (a judicial institution linked to the Council of Europe, not the EU); the assumption is that given these precedents in the European Court of Human Rights, the commission would not find differently. ${ }^{33}$

\section{The Headscarf as a Marker against Secularism}

As evidenced by the language of the BadenWürttemberg ban, the discussions surrounding this case have constructed Christianity and the West as per se supportive of freedoms and the liberal democratic order. Their relationship to secularism, then, does not need to be examined. By definition, they support secularism (and as I discuss below, European tolerance). Throughout the Ludin case, the covering or revealing of her body became the marker of her ability to participate in a modern, Enlightened German or European society, defined by its values of secularism and tolerance. The content of these relationships is deeply contradictory. While Ludin was initially challenged for not being Christian, she was later perceived to be unable to fulfill her duties because she was inadequately secular. Both positions construct the Muslim woman as inherently unable to emerge into a position as subject of the German state, unable to participate in European democracy. The shifting and contradictory meanings of the headscarf converge, however, in their exclusion of women of immigrant heritage from cultural, economic, and political citizenship. A certain consistency emerges primarily in terms of the regulation of otherness in order to manage a Europe constructed as secular norm. This is particularly apparent in the dissenting opinion in the Federal Constitutional Court's decision, which argues that the headscarf potentially endangers the "religious peace in society." ${ }^{4}$ Thus the headscarved woman not only is unable to emerge as a European subject but also serves as the marker of a threat to foundational notions of that subject. The differential laws that emerged following this case suggest in fact that Christianity is being privileged as a tradition informing the secular German state. However, exclusion is founded not by any action of Ludin's but rather by the possible interpretations of her headscarf in the future. This becomes a sort of phobia, as Claudia Breger points out, of the uncontrollable resignification of the headscarf. ${ }^{35}$

\section{The "Conflict of Cultures":}

\section{Secularism as Battle between Tolerance and Condemnation of Violence against Women}

In the press, courts, and legal scholarship, secularism discussions are often framed as a "conflict of cultures" that reveals the "true danger" of Islam in Europe, and one that occurs because immigrants do not arrive from "secular countries"-Germany is suffering from "foreign religiosity." ${ }^{36}$ In the context of the headscarf debate, the notion of the clash of cultures became a debate about tolerance with two streams: what decision would demonstrate "European tolerance" vis-à-vis an intolerant Islam and how much tolerance was too much. One can see this in particular as courts seek to legitimate the existence of crucifixes in the schools while simul-
33. For a more complete overview, see Weber, "Cloth on Her Head."

34. BverfG, 2 BVR 1436/O2 vom 3.6.2003, par. 99.

35. See Breger, "Religious Turns," 23.

36. Johann Bader, "Darf eine muslimische Lehrerin in der Schule ein Kopftuch tragen?" ("Can a Muslim Teacher Be Permitted to Wear a Headscarf in the School?"), Verwaltungsblätter für Baden-Württemberg 19, no. 10 (1998): 365; Ulf Häußler, "Religion und Integration," Zeitschrift für Ausländerrecht und Ausländerpolitik 19, no. 1 (1999): 36; Helmut Kerscher, "Ein Stück Stoff und seine Folgen" ("A Piece of Cloth and Its Consequences"), Süddeutsche Zeitung, 4 June 2003 , sec.
Themen des Tages; Michael Bertrams, "Lehrerin mit Kopftuch? Islamismus und Menschenrecht" ("Teacher with Headscarf? Islamism and Human Rights"), Deutsches Verwaltungsblatt, no. 19 (2003): 1225-34; Bundesverwaltungsgericht, "Die Einstellung als Lehrerin an Grund- und Hauptschulen im Beamtenverhältnis auf Probe" ("The Appointment of a Teacher to Elementary and High Schools as a Civil Servant in Training"), Juristen Zeitung 58, no. 5 (2003): 254; Helmut Goerlich, "Distanz und Neutralität im Lehrberuf-zum Kopftuch und anderen religiösen Symbolen" ("Distance and Neutrality in the Teaching Career-On the Headscarf and Other Religious Symbols") Neue Juristische Wochenschrift, no. 40 (1999): 2929-33; Martin Morlok and Julian Krüper, “Auf dem Weg zum 'forum neu-
trum'?-Die 'Kopftuch-Entscheidung' des BverwG" (“On the Way to a 'Forum Neutrum'? The Headscarf Decision of the Federal Administrative Court"), Neue Juristische Wochenschrift 56 (2003): 1020-21; and Burkhard Schöbener, "Die 'Lehrerin mit dem Kopftuch'-europäisch gewendet!" ("The 'Teacher with the Headscarf'-Turned toward Europe!"), Juristische Ausbildung, no. 3 (2001): 186. 


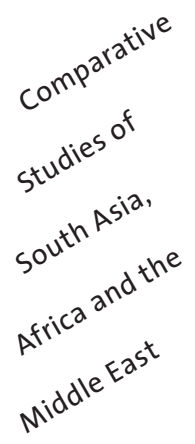

taneously denying Muslim symbols: "Children associate little with the mere everyday object on the wall, which demonstrates no immediate relationship to a concrete person or to facts of life [Lebenssachverhalt]. The crucifix is so much-beyond its religious meaning - a general cultural symbol for a culture which is rooted firmly in values drawn from Jewish and Christian sources, yet is open and has become tolerant through rich but also tragic [leidvoll] historical experience." ${ }^{37}$ This explanation of the crucifix is typical of a larger tendency to assume that Christianity (sometimes expressed as Judeo-Christian culture) inherently is more capable of being tolerant than Islam is, although this citation is unique in its pointing to fascism as a cause of that tolerance. Ludin embodies the cultural opposite of emancipation because the headscarf reveals Islam's tendency toward violence, as well as cultural exclusion, while tolerance becomes exclusively Christian: "Tolerance of those who think differently is a particular cultural marker of Christianity." ${ }^{38}$ The converse is also true: permitting the headscarf would merely evidence Christian tolerance: "Shouldn't this headscarf, the symbol of a supposedly repressive religion, be banned in the name of progress? Or wouldn't it be precisely an exemplary sign of Western tolerance to permit the headscarf?" 39

Ludin's insistent self-representation, and her desire to claim rights as a citizen in German democracy through recourse to the constitutional court, is obscured by the emphasis on cultural clash framed as conflict between a peaceful, tolerant state and the violence of Islam. The violence of Islam against women, it is perceived, will rise if headscarves increase their presence in the German public. This location of violence within the Muslim family functions in a twofold way: to limit the emergence of the Muslim subject to the public sphere via relocation to the private sphere of the family and to obscure the forms of racism that may be preventing the emergence of the immigrant woman as political subject.

Feminist responses have been particularly contentious. In the case of Ludin, responses were dominated by Alice Schwarzer, a mainstream feminist who even today continues to be the public face of German feminism - to the frustration of many feminists, however-and by women of Muslim heritage who reject Islam and argue that Islam is fundamentally incompatible with women's rights. The feminist responses receiving the most attention belie research that suggests that many women who choose the headscarf also insist on women's autonomy in work, education, and relationships. ${ }^{40}$ While the only mainstream feminist publication, EMMA, founded by and still largely influenced by Schwarzer, most recently has begun to include stories providing perspectives complicating the role of the headscarf in German culture, such feminist responses continue to be dominated by perspectives arguing that opposing the headscarf ban is a sign of either "too much" or "naive" tolerance, while the headscarf is per se a symbol of Islamic fundamentalism. ${ }^{41}$

\section{The Murder of Marwa el-Sherbini}

When el-Sherbini was murdered in a German courtroom, she had just completed her testimony against the right-wing NPD sympathizer Wiens, who had appealed his fine for insulting speech against el-Sherbini, having called her a terrorist and Islamist. In the courtroom, Wiens
37. BverfG, 2 BVR 1436/O2 vom 3.6.2003, par. 113.

38. Dieter Bednarz, “Allah-Mania," Spiegel Special, no. 1 (1998): 112. On Islam's tendency toward violence, see Wulf Reimer, "Kopftuchstreit in Plüderhausen: Eine muslimische Pädagogin verwirrt BadenWürttemberg" ("Headscarf Debate in Plüderhausen: A Muslim Teacher Confuses Baden-Württemberg”), Süddeutsche Zeitung, 8 July 1998, sec. Nachrichten; Brigitte-Johanna Henkel-Waidhofer, “'Man könnte meinen, die Türken stehen wieder vor Wien': Hitzige Debatte im Südwesten über Lehrerin mit Kopftuch; Landesregierung muss entscheiden" ("One Would Think That the Turks Are at the Gates of Vienna Once Again: Heated Debate in the Southwest about a Teacher with a Headscarf; The Provincial Parliament
Must Decide"), AP German Worldstream (Stuttgart), 8 July 1998; and Alfred Behr, "Muslimin beschäftigt den Stuttgarter Landtag" ("Stuttgart Parliament Concerned with Muslim Woman"), Frankfurter Allgemeine Zeitung, 11 July 1998, sec. Politik. On Islam's tendency toward cultural exclusion, see Brigitte J. Waidhofer, "Lehrerin mit Kopftuch" ("Teacher with Headscarf”), AP German Worldstream, 13 July 1998.

39. Bednarz, “Allah-Mania," 112.

40. See Sigrid Nökel, Die Töchter der Gastarbeiter und der Islam: Zur Soziologie alltagsweltlicher Anerkennungspolitiken; eine Fallstudie (Daughters of the Guestworkers and of Islam: Toward the Sociology of Everyday Politics of Recognition: A Case Study) (Bielefeld, Germany: Transcript, 2002).
41. On the role of the headscarf in German culture, see Lamya Kaddor, "Wäre Gott heute für das Kopftuch?" ("Would God Be for the Headscarf Today?"), EMMA, September-October 2009. On the headscarf as a symbol of Islamic fundamentalism, see Elisabeth Badinter, "Das Kopftuch ist ein Symbol" ("The Headscarf is a Symbol"), EMMA, September-October 2009; and Alice Schwarzer, "Kein Kopftuch in der Schule!" ("No Headscarf in the School!"), EMMA, September-October 2009. 
continued his racist speech, declaring that Muslims and non-Europeans had no right to be in Europe. El-Sherbini's story challenges the narratives about Muslim women in several ways. When Muslim women seek to wear the headscarf while working as public school teachers, the headscarf is seen as evidence that Muslim women are victims of Muslim patriarchy and pawns of Islamist movements. Yet like Ludin, elSherbini was a self-assured woman claiming her rights under German law in the German court system-even though not a citizen. Her death was not at the hands of a family member-indeed, her husband was shot by a policeman who entered the courtroom after the stabbing and assumed the husband was the perpetrator. The discourse at home and abroad largely transformed her from an active participant in the democratic process to a hijab martyr.

The German Central Council of Jews as well as the German Central Council of Muslims both gave public statements condemning the crime, but federal and local officials were slow to react publicly to the murder. Wiens was convicted of murder. All court officials were cleared of any wrongdoing in the shooting of el-Sherbini's husband. In 2010 the media researcher Sabine Schiffer was charged with slander and fined $€ 6$,ooo or two months' imprisonment because she stated in an interview that the mistaken shooting of the victim's husband by a police officer must be examined for possible racist connections (upon appeal, these charges were dropped).

Though the headscarf was not specifically mentioned in the complaint against Wiens, the fact that el-Sherbini wore a hijab was perceived to be provocation for both the verbal attack and the murder. Her murder was seen internationally as indicative of a growing German and Eu- ropean Islamophobia. ${ }^{42}$ Also widely reported

were the contradictory reactions of el-Sherbini's family: the father calling for an end to all forms of hate, the brother swearing vengeance. ${ }^{43}$ As this reaction widened to the US and the British press, increasing pressure was put on German media and government officials to respond to the crime; seven days after the murder, stories began appearing. These stories drew connections from el-Sherbini's murder to the $\mathrm{Mu}$ hammad cartoons that appeared in Denmark in 2006-NOT, however, to the case of Ludin. Those connections already suggest a German imagination of a chaotic "overreaction" on the part of the Muslim world, as responses to the cartoon controversy were often portrayed.

\section{Racist Germany?}

When the media and government officials began to respond, it was often to point out why this case does Nот indicate German racism. One Dresden official even claimed that clearly Dresden was not racist, since he himself had a Korean wife. ${ }^{44}$ The charges brought against media researcher Schiffer in 2010 for suggesting that racism might have led to the shooting of el-Sherbini's husband show the fear of naming racism as existing outside of the action of individuals, as potentially even present in German institutions, even as they also function to prosecute hate speech. When the crime is labeled xenophobic, racist, or Islamophobic in motivation, the crime is seen as a rare crime committed by a fanatic individual. ${ }^{45}$ Potential violence, however, threatens from without in the imagination of masses of Muslim protestors who were pictured in the news coverage that did exist.

In many cases the media emphasized that Wiens was a so-called Russlanddeutscher-a Russian of German heritage. Because of Germany's
42. See "Murder of Egyptian Woman and Islamophobia," Korea Times, 19 July 2009; Kate Connolly and Jack Shenker, "Racism Row: The Headscarf Martyr; Murder in German Court Sparks Egyptian Fury at West's 'Islamophobia,'” Guardian, 8 July 2009, final edition; Alaa Al Aswany, "Egyptian Author on Murdered Muslim Woman: 'The Reaction of the German Government Was Not Fair,'” by Volkhard Windfuhr and Bernhard Zand, Spiegel Online, 20 July 2009, www .spiegel.de/international/world/o,1518,637805,00 .html; “Afghan Daily Condemns Silence over Action against Uighurs in China," BBC Monitoring Trans Caucasus Unit Supplied by BBC Worldwide Monitoring,
12 July 2009; Birgit Cerha, "Die Wut Ägyptens; Islamische Welt über Bluttat entsetzt" ("Egypt's Anger; Islamic World Horrified by Bloody Murder"), Frankfurter Rundschau, 13 July 2009; "Egyptian Fury at Dresden Murder: Protestors Accuse Germany of Racism," Spiegel Online, 7 July 2009, www.spiegel.de/ international/world/o,1518,634842,0o.html; "Iranians Protest Killing of Veiled Egyptian Woman in Germany," BBC Monitoring Trans Caucasus Unit Supplied by BBC Worldwide Monitoring, 11 July 2009; and Alaa Al Aswany, "Western Hostility to Islam Is Stoked by Double Standards and Distortion," Guardian, 21 July 2009, final edition, sec. Comment and Debate.
43. See Cerha, "Die Wut Ägyptens."

44. See Wolf Schmidt, "Vorwärts und vergessen?" ("Forward and Forget?") Taz, Die Tageszeitung, 24 July 2009.

45. See Andrea Dernbach, "Weiße Rosen für Marwa" ("White Roses for Marwa"), Der Tagesspiegel, 12 July 2009, sec. Politik. 


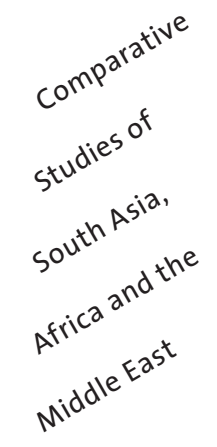

historic policies of privileging "blood" in immigration to Germany, Russians of German heritage were considered desirable immigrants until recently and thus were given relatively easy access to citizenship. In the initial stories about el-Sherbini, there was an anticipation of a discovery that Wiens's Islamophobia had been "pre-programmed" during his time in Russia. ${ }^{46}$ Repeatedly, comments asserted that Germany is not Islamophobic and that Wiens's emigration from Russia contradicts accusations of a German Islamophobia: "What does this uprooted man have to do with us Germans?" ${ }^{47}$ Indeed, the murder supposedly tells us "as much about the dominant Islamophobia in Russia as about xenophobia in Germany." 48 One of the few stories to actually take on the impacts of this murder for debates on multiculturalism in Germany, published in the Süddeutsche Zeitung, drew parallels to the 1992 Los Angeles riots and suggested that el-Sherbini's murder was the consequence of conflict between two "niche cultures." 49 This desire to locate the roots of violence outside of "German" culture is reinforced by an absence. The Russlanddeutscher, once understood as "German" enough to be a more desirable immigrant, now is conveniently "not German." Wiens is unproblematically referred to as a Russlanddeutscher now to emphasize his difference from Germanness. This can cover up the racialized understandings of Germanness that led to a notion of the Russlanddeutscher in the first place. ${ }^{50}$

Certainly, in this case it is important to acknowledge where the German legal system was working against racist speech. This suggests that a German secularism has emerged in which a subject might be marked by difference and yet be able to claim some rights under German law. The functioning of the legal system in the regulation of hate speech, however, does not serve as evidence that racism or Islamophobia is absent. When one considers el-Sherbini's murder and the responses to it in comparison to the ongoing and extensive discussions about the headscarf debates, it becomes obvious that the focus on the headscarf can indeed function to obscure forces of discrimination in German society.

Feminists in Germany have further been slow to consider el-Sherbini's murder as a problem relevant to feminist analysis. This response is partially due to a thorny problem facing analyses of violence against women. How can one challenge the representations of Islam as inherently violent, of Muslim men as inherently violent, and also challenge the violence against Muslim women that does exist? Western feminists have largely failed to find an alternative way to talk about violence that would allow for productive engagement with Islam. And those who seek to take on these difficult questions are largely ignored by the German government as well as by the mainstream media, which instead consistently turn to a very few voices who insist on total rejection of Islam.

The media coverage of el-Sherbini's death reveals issues that would seem to call for a feminist response. For example, most initial press coverage states that Wiens also called el-Sherbini an Islamist whore. According to Steffen Winter, who was a rare journalist to actually examine el-Sherbini's complaint and testimony, she denied this claim. ${ }^{51}$ She brought her complaint to reject her positioning within German society as a terrorist and Islamist. While she may have attempted to depoliticize the headscarf, and degender her claims to human rights, the repeated circulation of a notion of an "Islamist whore" suggests the power that the sexualization of the Muslim woman's body continues to have in German discussions of integration.
46. Hannes Heine, "Am Start für den Staat Opfer der Hetze: Die offenbar rassistische Messerattacke auf eine Ägypterin im Landgericht Dresden wird zunehmend zu einem Politikum; Warum ist die Tat so brisant?" ("At the Start for the State, Victims of Inflammatory Speech: The Apparently Racist Stabbing of an Egyptian in the Provincial Court of Dresden are Increasingly Becoming Political; Why is The Crime So Controversial?"), Der Tagesspiegel, 9 July 2009, sec. Zweite.

47. Sibylle Krause-Burger, "Ein Unbehauster in seinem dumpfen Drang" (“A Man without a Home, His Listless Urge"), Stuttgarter Zeitung, 15 July 2009.
48. Tomas Avenarius, "Empörung in Alexandria: Proteste nach Mord an Ägypterin in deutschem Gerichtssaal" ("Outrage in Alexandria: Protests after the Murder of an Egyptian Woman in a German Courtroom") Süddeutsche Zeitung, 7 July 2009, sec. Panorama.

49. Andrian Kreye, "Kampf der fremden Kulturen: Die Multikulturalismus-Frage im Messermord von Dresden" ("Battle of Foreign Cultures: The Question of Multiculturalism in the Dresden Stabbing"), Süddeutsche Zeitung, 14 July 2009.
50. While I cannot address this in detail here, it is interesting to note that Swiss newspapers expressed outrage that el-Sherbini's case was receiving so much more interest than violent attacks by youth against Swiss tourists in Munich were given. See "Bluttat mit internationalen Konsequenzen: Ein Mord in Dresden erregt Empörung in der muslimischen Welt" ("Bloody Deed with International Consequences: A Murder in Dresden Causes Outrage in the Muslim World"), Neue Zürcher Zeitung, 14 July 2009.

51. See Steffen Winter, “Justiz: 'Bloßer Hass,'” (“Justice: Simple Hate"), Spiegel Online, 31 August 2009, www .spiegel.de/spiegel/o,1518,646122,00.html. 
While accusations of Islamophobia or racism are firmly rebuffed, the state is willing to entertain the possibility that security may be lax in German courtrooms. ${ }^{52}$ An investigation was opened into the possibility that the presiding judge inadequately provided for el-Sherbini's security in the courtroom, though no charges were brought. Necla Kelek, an outspoken proponent for a headscarf ban, sees el-Sherbini as doubly victimized: by the headscarf, which she argues is necessarily oppressive to women, and by the court's inability to protect. ${ }^{53}$ The discourse of security removes el-Sherbini from her active participation in German democracy through claiming antidiscrimination protection and testifying at the trial. Instead, el-Sherbini is located as the recipient of physical protection at the hands of the court, as paternalistic representative of the state.

\section{Reconfiguring the Public Sphere?}

One must, however, consider the ways that discussions in the wake of el-Sherbini's murder may be functioning to reconfigure the public sphere. While it was an argument rarely attended to in the press, Stephan J. Kramer, the general secretary of the Central Council of Jews, responded early to the murder by arguing that attacks based on race, religion, or nationality are fundamentally attacks on democracy itself. Kramer's remarks evoke the potential for a secular democracy that does not regulate difference through a condescending tolerance. Instead Kramer seeks to respond to the "largely unchecked hate propaganda against Muslims spread by everyone from marginal extremists right through to people at the centre of society" with the hard work of respect. ${ }^{54}$

Journalist Hilal Sezgin also seeks to recognize and name racism in her contributions to the online version of a popular Berlin daily newspaper, the Tageszeitung. She counters the claim that accusations of Islamophobia or discrimination against Muslims are merely appro- priations of el-Sherbini's death by Egypt and 113 Iran. ${ }^{55}$ Sezgin evades the reduction of racism to an individual act, reminding the public that a racist act gains its significance in a specific context. She also criticizes the many voices who have argued that if any country knows how to be selfcritical when it comes to racism and violence, it is Germany. Germany will demonstrate such maturity, she contends, not by being insulted by claims of discrimination but by being disturbed enough to investigate whether such claims are true. She argues,

The growth in Islamophobia in Germany means, for example, that a pattern has been established in our public speech that evokes specific images (veiled women, scenes of masses of raised behinds in prayer), ignores some questions ("Why doesn't Islam possess the same legal rights as the Churches?"), and privileges others ("Why have they still not learned any German?). This pattern classifies members of a population group through stereotypes, and allows the individuals to appear more as performing mouthpieces of their supposed "culture" than as individual actors with their own preferences and decisions. ${ }^{56}$

Sezgin's discussion suggests that Islamophobia functions specifically through the regulatory practices of secularism. These reduce representations of individuals to their association with Islam, while ignoring the structural privileging of Christianity-for example, through contracts with the state.

Andreas Fanizadeh, also in the Tageszeitung, criticizes the inability to name and confront racism from a different perspective. He emphasizes that the reduction of this act to a question of Left versus Right also prevents everyday Germans from working to prevent racism. ${ }^{57} \mathrm{He}$ further argues that while laws have improved for minorities living in Germany, who are discovering more trust in German civil society, these improvements have come at the cost of increasing attempts to cut off further immigration.
52. See "Bluttat mit internationalen Konsequenzen."

53. See Necla Kelek, "Verstoß gegen die Menschenwürde" ("A Violation of Human Dignity"), EMMA, September-October 2009, 98-99, www.emma.de/ ressorts/artikel/kopftuch-burka/verstoss-gegen -die-menschenwuerde/.
54. Stephan J. Kramer, "In Solidarity with All Muslims," Qantara.de, 13 July 2009, www.qantara.de/ webcom/show_article.php/_c-476/_nr-1187/i.html.

55. See Hilal Sezgin, "Das reine deutsche Gewissen" ("The Pure German Conscience"), Taz.de, 22 July 2009, www.taz.de/1/debatte/kolumnen/artikel/1/das-reine -deutsche-gewissen/.
56. Ibid.

57. See Andreas Fanizadeh, "Aufstand der Anständigen?" ("Revolt of the Respectable?"), Taz, Die Tageszeitung, 18 July 2009, sec. Meinung und Diskussion. 


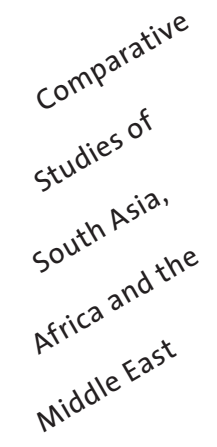

\section{Headscarves, Violence, and the Potential for Critique}

The relative inattention to the el-Sherbini case is indicative of the effectiveness of the discourses that were created during the headscarf debates. The headscarf can trigger an already existing set of discursive regimes that assumes the totality of a successful tolerant secularism that constructs a nonviolent European heritage. The reference to the headscarf activates a tradition that has located the origins of violence-primarily as gendered violence-so firmly elsewhere that Germany is successfully able to evade a discussion of forms of racialized violence within its own borders.

The power of this discourse challenges the potential for critique within critical theory. As I outlined earlier, the notion of critique emerges from a tradition that specifically links critique to a secular position. Criticism might be seen as directed at an object or phenomenon, while critique is directed at the conditions under which an object or phenomenon can come into being; the existence of that very distinction, however, has long been associated with the critique of religion itself. How, then, to turn critique against itself- to direct critique at the very notion of secularism as it is raised by debates on headscarves and veils? In a different context, Judith Butler sees one possibility in the work of Walter Benjamin, in that he continually points to an interruption in the narrative of Enlightenment progress that occurs when the premodern erupts into the modern..$^{58}$ Alternatively, Butler suggests, one might turn to the work of Michel Foucault, who conceptualized critique as an attitude outside of a Kantian regime of reason and saw it both as a challenge to the evaluative frameworks within which criticism occurs and as an interrogation of the conditions under which the subject emerges. ${ }^{59}$ My analysis implies similar questions: under what conditions does the headscarf come to signify the violence and danger of Islam? What frameworks enable the public criticism of the headscarf? What are the conditions for the coming-into-being of the secular subject, the subject who can act as agent in the public sphere? The cases of Ludin and elSherbini point to the need for a critical project that interrogates secularism itself as the framework within which the headscarf is judged.

A juxtaposition of the discussions of the Ludin and el-Sherbini cases reveals much about these questions. While Ludin's case can be used to illustrate the supposed arrival of a threatening Islam into the heart of Europe's democratic institutions, el-Sherbini's murder in a German courtroom is used both to discursively expel the roots of violence from Europe (by locating systemic violence in Russia and Egypt, while representing el-Sherbini's murder as an isolated incident) and to legitimate increased emphasis on security.

These two women both sought active participation in public debate and temporarily negotiated a position in a secular public spherenot only with the headscarf but because of it. Yet the headscarf ultimately leads to their expulsion from the public sphere. This occurs metaphorically in the case of el-Sherbini, when public memory marks her as victim but excludes her as agent in a democratic process. Ludin's expulsion is not only from the public sphere but from a special public space, when she is denied a position as a public teacher. The headscarf thus occupies an ambivalent function: it serves as the means by which these women emerge into public space, but ultimately, it also acts as the marker of cultural otherness that prohibits their participation in a democratic public sphere. The subject of democracy remains abstracted and unmarked but firmly "European." The field thus constituted can only partially represent the subject of democracy as wearing a hijab; she is quickly appropriated as the victim of external violence, or she disappears entirely.

The use of cultural difference to obscure the question of racist violence evokes the tradition of legitimizing violence against peoples of color in colonialist discourses through the reference to a backwardness that must be "enlightened" through European conquest. ${ }^{60}$ This
58. See Judith Butler, "The Sensibility of Critique: Response to Asad and Mahmood," in Asad et al., Is Critique Secular?, 110-11.

59. See ibid., 112-14. 6o. See Beverly M. Weber, "Freedom from Violence, Freedom to Make the World: Muslim Women's Memoirs, Gendered Violence, and Voices for Change in Germany," in Women in German Yearbook 25 (2009): 202-4; Uma Narayan, Dislocating Cultures: Identi- ties, Traditions, and Third-World Feminism (New York: Routledge, 1997), 83-117; Gayatri Chakravorty Spivak, A Critique of Postcolonial Reason: Toward a History of the Vanishing Present (Cambridge, MA: Harvard University Press, 1999), 288-89; Cengiz Barskanmaz, 
leads to another difficulty for the potential for critique, when critiques of Islamophobia in turn themselves become associated with antiEnlightenment ideals. While this happens frequently in public discussions of the headscarf, a particularly obvious example occurs in a leftist magazine for politics and culture, Konkret. An October 2009 issue illustrates a discussion between two journalists about the potential for a critique of Islam with a cover image of a woman whose face is completely covered by a niqab. One journalist, Kay Sokolowsky, takes the position that the critique of Islam, while necessary, has been appropriated by racists, while the other, Alex Feuerherdt, argues that Islam should be understood per se as a reactionary, antimodern political ideology. Again, the veiled Muslim woman serves as the emblem for a debate about the relationship between Islam and modernity. She marks not only the limits of "tolerance" but also the limits of enlightened antiracism. Secularism itself, alternatively, remains outside the possibility of critique, which in the logic of this discussion can only be directed at Islam itself.

The discursive exclusion of Muslim women from democratic participation is incomplete, however, and reveals ruptures that may have been forced precisely by the inability to engage with the racist violence that emerged in the face of el-Sherbini's success in a battle against racist speech. Since el-Sherbini's murder, many women have expressed a new willingness to acknowledge experiences of discrimination owing to the wearing of a headscarf. ${ }^{61}$ Sezgin's and Fanizadeh's contributions to the discussion cited above, while evoking little response, nevertheless emerged in a forum with fairly wide readership. They seek to consider an institutionalized racism that could exist outside of individual intent and consciousness and to place Wiens's actions firmly in that context. These are all ways in which constructions of sec- ularism, democracy, and religion will continue to be negotiated and renegotiated in the public sphere, as Muslims see themselves increasingly empowered to challenge Islamophobia in public institutions.

An approach to European secularism that derives from the assumption of a European history that promotes peace, juxtaposed with a Muslim tradition that promotes violence, not only obscures Europe's own history of colonial and racist violence but actually prevents Muslim women from participating in the public sphere. A vision of democratic modernity rooted in the exchange of ideas in the public sphere will always be thwarted so long as these blind spots in European history prevail. However, the headscarf discussions, read together, also reveal an alternative, reconfiguration of the public sphere. They point to the possibility for a critique of secularism that can function without the epistemic violence of constructing an other. This reconfigured sphere activates the desire for a utopian Europe that prioritizes human rights in the service of a revised secularism. This revised secularism seeks to incorporate an understanding of difference into the public sphere, beyond notions of tolerance, in order to reveal the structures of xenophobia, racism, or Islamophobia at work. Such a secularism would imagine the elimination of racist violence as part of the larger goal of religious peace. Such a secularism also could imagine the headscarved teacher participating in a secular democratic public sphere and acknowledge xenophobic attacks as examples of existing racist violence. Only in this way could democratic structures be imagined that ban rather than regulate violence. 9

\footnotetext{
"Das Kopftuch als das Andere: Eine notwendige postkoloniale Kritik des deutschen Rechtsdiskurses" "The Headscarf as the Other: A Necessary Postcolonial Critique of the German Discourse of Justice"), in Der Stoff, aus dem Konflikte sind: Debatten um das Kopftuch in Deutschland, Österreich und der Schweiz (The Cloth of Which Conflicts are Made: Debates about the Headscarf in Germany, Austria, and Switzerland), ed. Sabine Berghahn and Petra Rostock (Bielefeld, Germany: Transcript, 2009), 362-64.
}

61. See Kübra Yücel, "Seit dem Mord reden wir offener" ("Since the Murder, We Speak More Openly"), Taz.de, 31 July 2009, www.taz.de/1/politik/deutsch land/artikel/1/seit-dem-mord-reden-wir-offener/. 